\title{
Abiotic effects on the cover and richness of corticolous lichens on
}

\section{Araucaria angustifolia trunks}

\author{
Lucas Nunes $^{1 *}$ (D), Giulia Burle ${ }^{1}$ (D), Emerson Luiz Gumboski ${ }^{2}$ and Michele Dechoum ${ }^{3}$ (1)
}

Received: March 14, 2018

Accepted: August 16, 2018

\begin{abstract}
Lichens play a key role in natural ecosystems, as they can function as primary producers, recycle minerals and fix nitrogen. Despite their environmental importance, little is known about lichen ecology in Brazil, and especially about how abiotic factors may influence their spatial distribution. In this study, we aimed to verify how the cover and richness of corticolous lichens on Araucaria angustifolia trunks vary between two different habitats (Forest and Grassland). The photoquadrat sampling method was applied to A. angustifolia trunks. The Coral Point Count software with Excel extensions ( $\mathrm{CPCe}$ ) was used to analyze photographs for lichen cover and richness. Additionally, a redundancy analysis was conducted to estimate how five abiotic and two biotic variables affected the spatial distribution of lichens. Twenty-five morphospecies were identified, none of them occurring exclusively in the Grassland habitat. Canopy openness, air humidity and tree trunk rugosity were important parameters influencing lichen distribution; therefore, spatial segregation of growth forms can be explained by environmental selectivity. Foliose lichens require more air humidity, which explains their predominance in the Forest habitat. Canopy openness in Grassland habitat favors fruticose lichens, which depend on factors such as wind for reproduction.
\end{abstract}

Keywords: Ascomycota, corticolous lichens, environmental selectivity, fungi, lichen ecology, niche overlap

\section{Introduction}

Lichens are symbiotic organisms formed by the association of one or more fungi (Ascomycota and/ or Basidiomycota) and microalgae (Cianophyceae or Chlorophyta groups; Beck et al. 1998; Marcelli 2006; Spribille et al. 2016). Lichens exist in a great diversity of shapes and sizes, and are considered a key group in ecosystem functioning for their role as primary producers (Büdel et al. 2014; Munir et al. 2015), atmospheric nitrogen fixers (Nash 2008) and for contributing to the cycling and incorporation of soil minerals (Cornelissen et al. 2007; Nash 2008; Concostrina-Zubiri et al. 2013). Furthermore, lichens are important bioindicators of environmental quality (Lemos et al. 2007; Gauslaa 2014; Perlmutter et al. 2017).

Lichens develop close interactions with living surfaces, such as tree trunks (Brodo 1973). These biological substrates provide favorable environmental conditions for lichen growth, such as substrate complexity and light conditions that are generally adequate for physiological responses by lichens (Brodo 1973; Nascimbene et al. 2009). In addition, the structural complexity of tree trunks, considering tree age and size, influence lichen richness, as older tree trunks tend to be rougher and favor establishment (Nascimbene et al. 2009).

Although lichens are present in different environments, their abundance and distribution are influenced by abiotic

1 Programa de pós-graduação em Ecologia, Universidade Federal de Santa Catarina, 88040-900, Florianópolis, SC, Brazil

2 Departamento de Ciências Biológicas, Universidade da Região de Joinville, 89219-710, Joinville, SC, Brazil

3 Programa de pós-graduação em Biologia de Fungos, Algas e Plantas, Universidade Federal de Santa Catarina, 88040-900, Florianópolis, SC, Brazil

* Corresponding author: nuneslteixeira@gmail.com 
factors that facilitate their development (Honda \& Vilegas 1998; Gauslaa 2014). Light availability and wind speed are among the most important factors, as they influence photosynthetic processes and spore/propagule dispersal, respectively (Heinken 1999; Palmqvist 2000; Nash 2008; Gauslaa 2014). Secondarily, air humidity and temperature determine colonization success, since they enable the photobiont to develop symbiotic interactions (Brodo 1973; Benítez et al. 2012; Gauslaa 2014). To determine how abiotic conditions influence the success of biological interactions is a key factor in understanding lichen distribution and abundance (Fedrowitz et al. 2012; Gauslaa 2014). The effects of abiotic factors on lichen distribution and richness are well known globally, as well as the importance of forest ecosystems as a matrix for lichen colonization and dispersal (Moning et al. 2009; McMullin et al. 2010; Gauslaa 2014). However, there are few studies on these factors in Brazilian ecosystems (Martins et al. 2011; Käffer \& Martins 2014), especially considering different habitats in Mixed Ombrophilous Forest (araucaria forest), for which there is scarce knowledge on lichen ecology (e.g. Fleig \& Grüninger 2008; Käffer et al. 2009; 2010; 2015; Koch et al. 2012; Hampp et al. 2018).

Araucaria angustifolia (Araucariaceae) is described as a predominant phytoecological unit in Mixed Ombrophilous Forest (Rondon Neto et al. 2002). Its distribution covers higher altitude areas between Rio Grande do Sul and Paraná states in southern Brazil, as well as small disconnected areas in São Paulo, Rio de Janeiro and Minas Gerais (Hueck 1953). The species has high ecological relevance, although the total cover of Mixed Ombrophilous Forest has been significantly reduced due to logging and conversion to agriculture (Borgo \& Silva 2003; Medeiros et al. 2005). Araucaria angustifolia is important for the recruitment of different epiphytic and arboreal species, increasing local diversity (Borgo \& Silva 2003; Fogaça et al. 2016). Ecological studies with corticolous lichens associated with $A$. angustifolia are still incipient (see Käffer et al. 2010), although it is acknowledged that the dominance of a particular lichen morphospecies may be indicative of certain environmental conditions (Nimis et al. 2002; Will-Wolf et al. 2006; Giordani et al. 2009) and anthropogenic effects on natural areas (Dettki \& Esseen 1998; Das et al. 2012; Li et al. 2013; Bähring et al. 2016).

Lichens exist in different growth forms as a result of the symbiotic interaction. These are defined as morphotypes. Crustose lichens are sessile and adhered to the substrate; foliose lichens grow leafy, lobular structures anchored in the substrate by a thallus or rhizine; and fruticose lichens have little contact with the substrate and grow as pendent, subpendent or shrub-like thallus (Hinds \& Hinds 2007; Nash 2008). The symbiont species in the interaction determines the lichen morphospecies, while the spatial distribution of each growth form may be correlated with the habitat where the symbiosis was established. This is justified by the influence of abiotic factors on the development, maintenance or replication of the symbiosis (Fedrowitz et al. 2012).

This study aimed to evaluate the influence of abiotic factors (i.e. canopy openness, air humidity, distance to a river, air temperature and wind speed) on the cover and richness of lichen morphospecies and growth forms associated with $A$. angustifolia (araucaria hereafter) in two different habitats in Mixed Ombrophilous Forest (Forest and Grassland). We hypothesized that differences in abiotic factors and vegetation structure between these habitats result in differences in lichen cover and richness.

\section{Materials and methods}

\section{Study area}

Field work was conducted in November 2017, in the daytime (9am - 5pm), on the Reunidas Campo Novo farm, located in the municipality of Bom Retiro (27 $53^{\prime} 58.28^{\prime \prime} \mathrm{S}$ $\left.49^{\circ} 26^{\prime} 11.06^{\prime \prime} \mathrm{W}\right)$, state of Santa Catarina, in southern Brazil (Fig. 1A). The climate is temperate oceanic, $\mathrm{Cfb}$ in the Köppen-Geiger classification system (see Pandolfo et al. 2002). Annual mean rainfall varies between $1500-1700 \mathrm{~mm}$, mean temperature between $17-18^{\circ} \mathrm{C}$, and mean air humidity between $82-84 \%$ in the summer (Pandolfo et al. 2002). Photoquadrat sampling was applied on araucaria trees in two Mixed Ombrophilous Forest habitats at a minimum distance of 360 meters ("Forest" and "Grassland" hereafter). These areas are located next to the João Paulo river. The Forest habitat is situated upstream and represented by riparian vegetation, characterized by high frequency of Araucaria angustifolia (Bertol.) Kuntze trees. The Grassland habitat is located downstream and characterized by the prevalence of herbaceous vegetation, mostly grasses with shrubs, and sparse A. angustifolia trees (Fig. 1B).

\section{Data collection}

In each habitat, four linear transects placed 30 meters apart were set up with the use of a measuring tape. The transects were $50 \mathrm{~m}$ long and $10 \mathrm{~m}$ wide (comprising an area of $500 \mathrm{~m}^{2}$ ). The photoquadrat sampling method (Fig. 1C) was applied to all araucaria trees in the transects at least 3 $\mathrm{m}$ distant from other araucaria trees and circumference at breast height $(\mathrm{CBH})$ larger than $50 \mathrm{~cm}$.

Canopy openness (measured with a spherical densitometer; Forest Model-C), air humidity (analogic hygrometer, Incotherm, \%), distance from the river (measuring tape, meters), air temperature (thermometer, ${ }^{\circ} \mathrm{C}$ ) and wind speed (anemometer Instrutherm THD-500, meters/second) were measured for each araucaria tree. All abiotic variables were measured within a three-hour interval on the northern side of the trunk, at a height of 1.3 meters from the ground. The biotic variables $\mathrm{CBH}$ $(\mathrm{cm})$ and trunk rugosity were measured in the same spot 
of the photoquadrat. Rugosity was visually estimated and categorized as low, medium or high. "Low" rugosity was characterized by smooth irregularities on the trunk, "medium" for shallow grooves and/or light cortex peeling, and "high" as deep grooves and advanced process of cortex peeling (Fig. 2).

The photoquadrat sampling method was adapted from the method described by Kohler \& Gill (2006), previously applied in studies on marine benthic organisms. A polyvinyl chloride $(\mathrm{PVC})$ rectangle was placed on the northern side of the trunk, and one $25 \times 10 \mathrm{~cm}\left(250 \mathrm{~cm}^{2}\right)$ photograph was taken at a minimum distance of $40 \mathrm{~cm}$ between the rectangle and the camera (Canon G15). The photographs were analyzed in the laboratory using Coral Point Count software with Excel extensions (CPCe 4.0 version 2006). Richness of morphospecies and cover of each of the
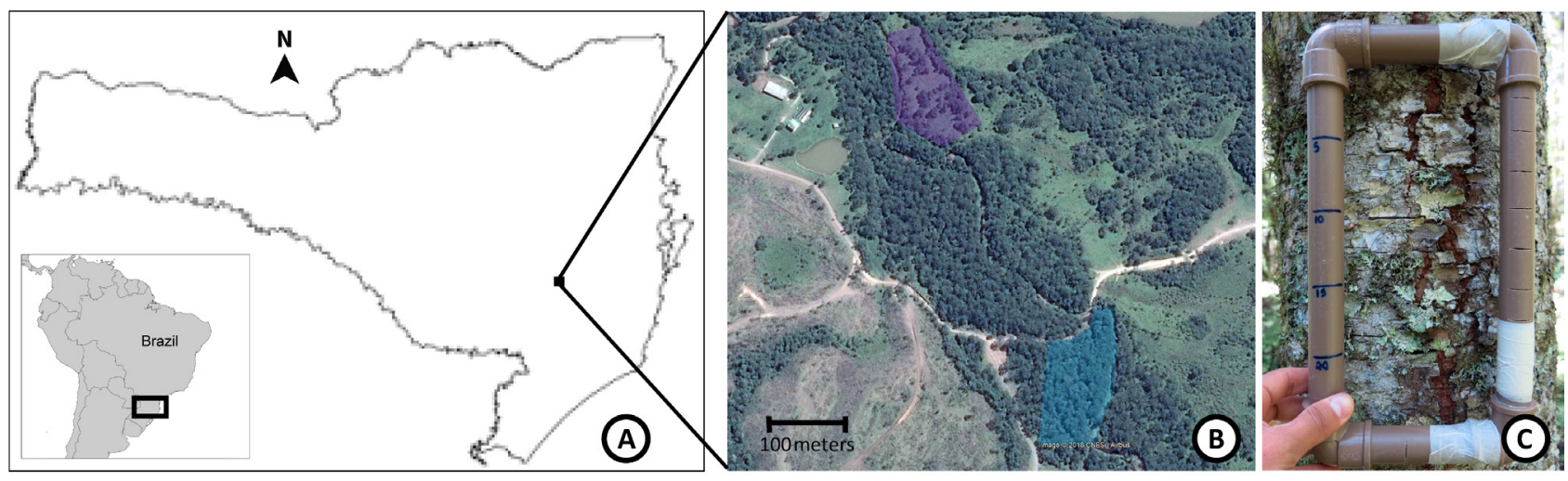

Figure 1. Location map of the study area and sampling method used for estimating lichen cover and richness. A. Map of Santa Catarina State, with the location of Bom Retiro (Black square); B. Study area on the Reunidas Campo Novo farm; blue and purple polygons define Forest and Grassland habitats, respectively; $\mathbf{C}$. The photoquadrat used to obtain images for each araucaria tree sampled.
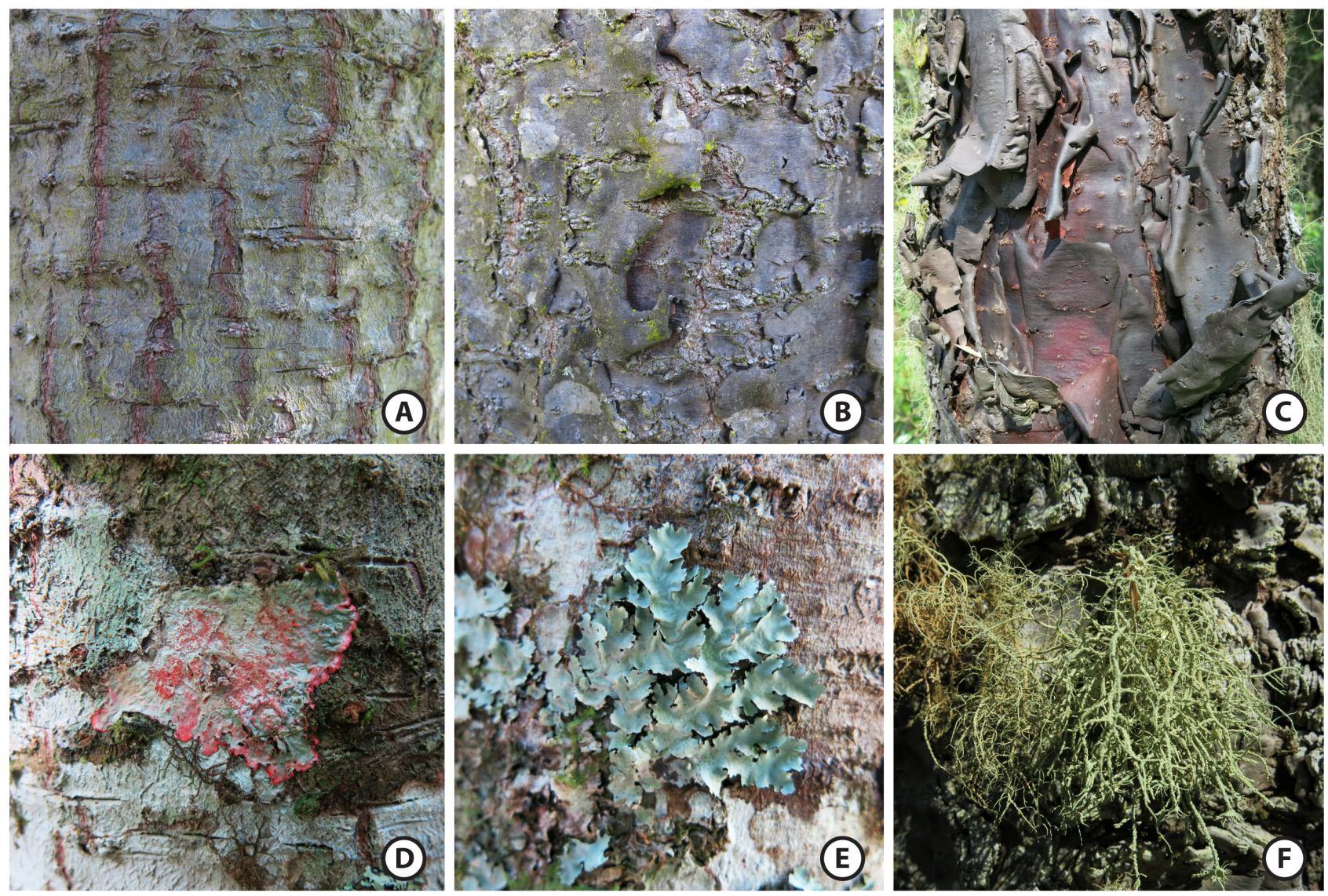

Figure 2. Rugosity categories of Araucaria angustifolia trunks (A. low rugosity, B. medium rugosity, C. high rugosity); and growth forms of lichens sampled in Mixed Ombrophilous Forest (D. crustose, morphospecies Herpothallon cf. rubrocinctum, E. foliose, morphospecies Parmotrema sp., F. fruticose, morphospecies Usnea sp.). 
three lichen growth forms were obtained by 30 randomly distributed points on each photo. The lichens at each point were identified and classified in one of the three growth forms: crustose, foliose or fruticose (Fig. 2). When the point fell on the cortex, bryophytes or pteridophytes, the element was termed "other". Once the lichens at each point were identified, the proportion of cover of each growth form was estimated in each photo by extrapolation using the $\mathrm{CPCe}$ software. The total cover of $100 \%$ corresponds to the sum of all organisms identified in every photoquadrat, and the total cover of each growth form corresponds to the average of each growth form for all trees sampled in "Forest" and "Grassland".

\section{Statistical analyses}

We performed a principal coordinate analysis ( $\mathrm{PCoA})$ to verify how the samples (tree trunks) were arranged regarding abiotic variables and a permutation analysis of variance (PERMANOVA) to test the null hypothesis that Forest and Grassland do not differ on abiotic terms. Abiotic variables were transformed by standardization to decrease data dispersion. We also performed a PCoA and a PERMANOVA to verify and test how lichen composition (morphospecies) varied between habitats.

To verify whether total cover and richness; and the cover of growth forms (i.e. crustose, foliose and fruticose) varied between habitats, we performed a Welch's t-test. To verify the influence of abiotic variables on lichen composition we performed a redundancy analysis (RDA) and a subsequent analysis of variance (ANOVA) of the canonical axes. All analyses were performed using the "vegan" (Oksanen et al. 2013) and "ggplot2" (Wickham 2009) packages of $R$ software (R Core Team 2017).

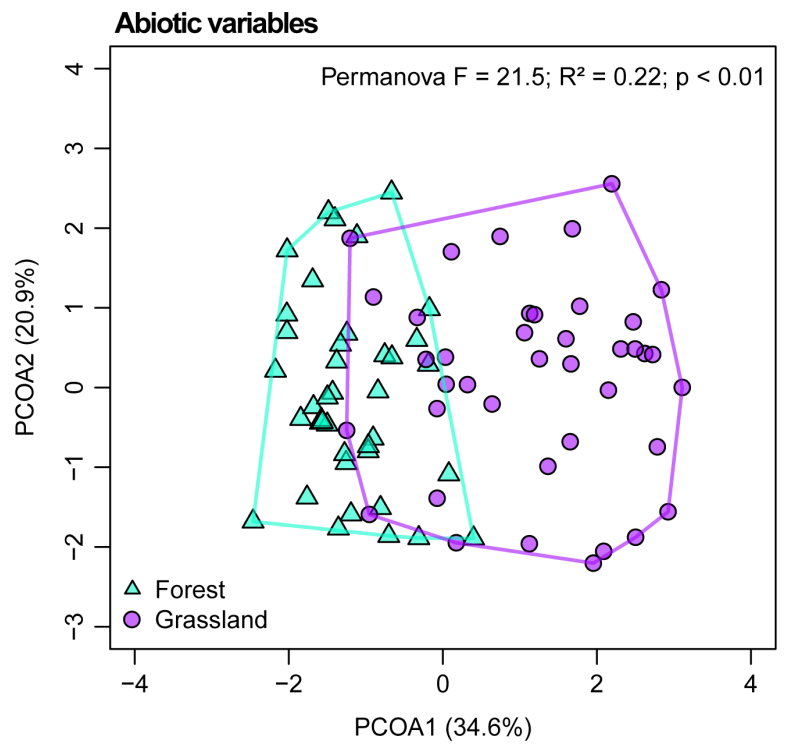

\section{Results}

A total of 80 araucaria trunks were sampled, 40 in each habitat (Forest and Grassland), on which 25 morphospecies of lichens were found. Seven of these were crustose, 11 foliose, and seven fruticose. While no morphospecies were exclusive to Grassland, 13 occurred only in Forest (Tab. 1). Although registered in the photographs, the morphospecies Ramalina cf. usnea and Phyllopsora sp. were not captured in the random point placement method due to restricted cover (Tab. 1).

The PCoA and PERMANOVA analyses showed that abiotic factors and lichen composition are different in Forest and Grassland (Fig. 3). Furthermore, in the samples located in Grassland a more diffuse pattern was observed for abiotic factors, with few samples overlapping Forest. On the other hand, samples in Forest presented a more diffuse pattern in lichen composition.

Lichen total cover differed between habitats ( $\mathrm{T}=21.8$; $\mathrm{DF}=79.1 ; \mathrm{p}<0.01)$, being higher in Forest (mean=47.9; standard error $= \pm 2.5)$ than in Grassland $(46.8 \pm 3.4)$. Total richness also differed ( $\mathrm{T}=14 ; \mathrm{DF}=93.2 ; \mathrm{p}<0.01)$, being higher in Forest $(4.6 \pm 0.3)$ than in Grassland $(3.88 \pm 0.26)$. The crustose growth form differed in cover $(\mathrm{T}=5.6$; $\mathrm{DF}=79.2 ; \mathrm{p}<0.01)$ and richness $(\mathrm{T}=-2.5 ; \mathrm{DF}=117.8$; $\mathrm{p}=0.01$ ) between habitats, being higher in Grassland (Fig. 4). The foliose growth form also differed in cover ( $\mathrm{T}=7.1$; $\mathrm{DF}=79.1 ; \mathrm{p}<0.01)$, but did not differ in richness $(\mathrm{T}=0.3$; $\mathrm{DF}=93.3 ; \mathrm{p}=0.75$ ); cover was higher in Forest (Fig. 4). Conversely, the fruticose growth form differed in cover ( $\mathrm{T}=7.8 ; \mathrm{DF}=79.1 ; \mathrm{p}<0.01)$, but did not differ in richness $(\mathrm{T}=0.1 ; \mathrm{DF}=99.2 ; \mathrm{p}=0.94)$; cover was higher in Grassland (Fig. 4).

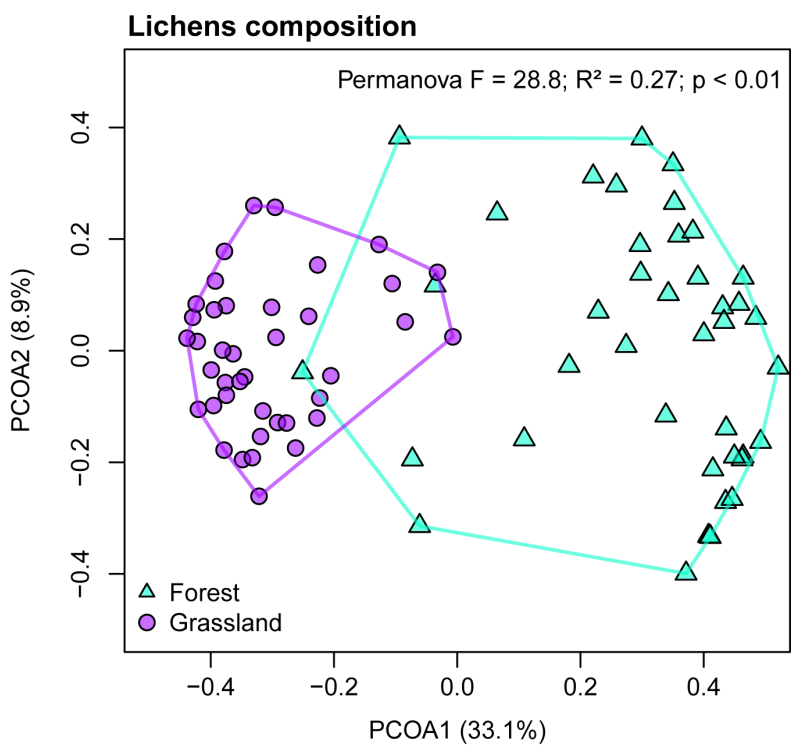

Figure 3. Principal coordinate analysis (PCoA) and permutational analysis of variance (PERMANOVA) performed with the abiotic variables and the composition of lichen morphospecies sampled in two habitats: "Forest" (Blue triangles) and "Grassland" (purple circles) in Mixed Ombrophilous Forest. 
Table 1. Morphospecies and growth forms of lichens on Araucaria angustifolia trunks sampled in two habitats ("Forest" and "Grassland") in Mixed Ombrophilous Forest.

\begin{tabular}{|c|c|c|c|}
\hline \multirow{2}{*}{ Morphospecies } & \multirow{2}{*}{ Growth form } & \multicolumn{2}{|c|}{ Habitats } \\
\cline { 3 - 4 } Chrysothrix sp.1 & Crustose & Forest & Grassland \\
\hline Chrysothrix sp. 2 & Crustose & $\mathrm{X}$ & $\mathrm{X}$ \\
\hline Graphis sp. & Crustose & $\mathrm{X}$ & $\mathrm{X}$ \\
\hline Herpothallon cf. roseocinctum & Crustose & $\mathrm{X}$ & - \\
\hline Herpothallon cf. rubrocinctum & Crustose & $\mathrm{X}$ & - \\
\hline Phyllopsora sp. & Crustose & - & - \\
\hline Trypetheliaceae & Crustose & $\mathrm{X}$ & $\mathrm{X}$ \\
\hline cf. Heterodermia & Foliose & $\mathrm{X}$ & - \\
\hline cf. Lobariella sp. & Foliose & $\mathrm{X}$ & - \\
\hline Dirinaria sp. & Foliose & $\mathrm{X}$ & - \\
\hline Heterodermia cf. leucomela & Foliose & $\mathrm{X}$ & - \\
\hline Heterodermia sp. & Foliose & $\mathrm{X}$ & - \\
\hline Parmotrema cf. clavuliferum & Foliose & $\mathrm{X}$ & - \\
\hline Parmotrema sp.1 & Foliose & $\mathrm{X}$ & - \\
\hline Parmotrema sp.2 & Foliose & $\mathrm{X}$ & - \\
\hline Parmotrema sp.3 & Foliose & $\mathrm{X}$ & $\mathrm{X}$ \\
\hline Physcia sp. & Foliose & $\mathrm{X}$ & - \\
\hline Punctelia sp. & Foliose & $\mathrm{X}$ & - \\
\hline Ramalina sp. & Fruticose & $\mathrm{X}$ & - \\
\hline Ramalina cf. sprengelii & Fruticose & $\mathrm{X}$ & $\mathrm{X}$ \\
\hline Ramalina cf. usnea & Fruticose & - & - \\
\hline Usnea cf. rubicunda & Fruticose & $\mathrm{X}$ & $\mathrm{X}$ \\
\hline Usnea sp.1 & Fruticose & $\mathrm{X}$ & $\mathrm{X}$ \\
\hline Usnea sp.2 & Fruticose & $\mathrm{X}$ & $\mathrm{X}$ \\
\hline Usnea sp.3 & Fruticose & $\mathrm{X}$ & $\mathrm{X}$ \\
\hline & & & \\
\hline
\end{tabular}

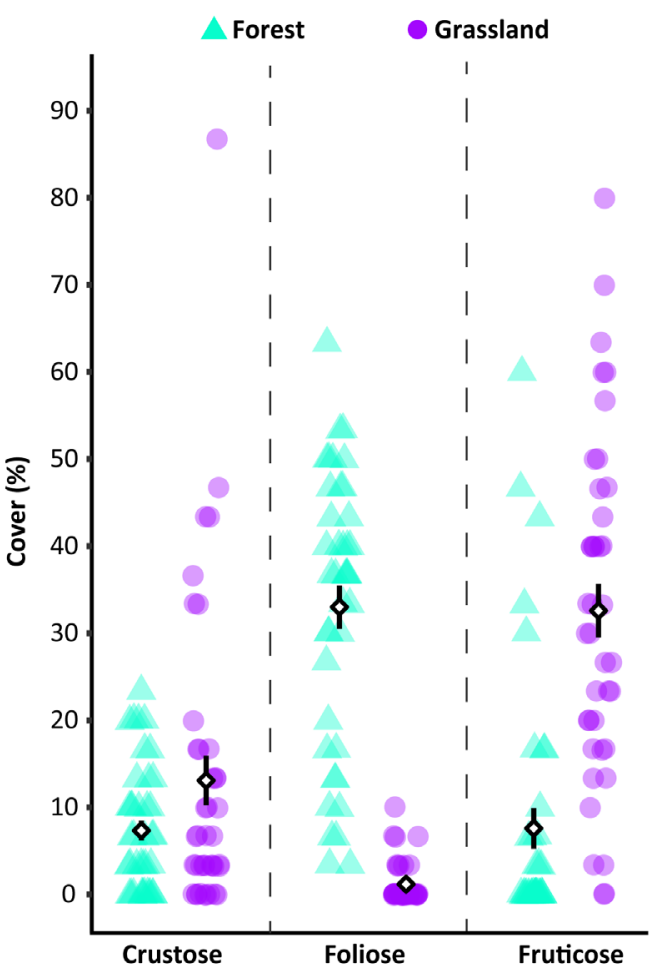

The RDA analysis showed that canopy openness, air humidity and trunk rugosity were the main abiotic factors influencing cover of the three growth forms (Fig. 5). The foliose growth form was more related to Forest, being positively influenced by humidity and $\mathrm{CBH}$, while the fruticose growth form showed the opposite pattern, being more related to Grassland and positively influenced by canopy openness. The crustose growth form was related to both habitats and inversely related to trunk rugosity (Fig. 5).

\section{Discussion}

In this study, we verified that the cover and richness of corticolous lichens on $A$. angustifolia trunks are determined by the environment in which the tree is growing, as a consequence of abiotic variables that can influence the selectivity of lichens for substrate type. The highest total cover and richness of lichens was found in Forest, where samples presented a more scattered pattern, indicating higher variation in species composition compared to Grassland. In terms of growth form, the cover by foliose lichens was higher in Forest, while the cover by fruticose and crustose lichens was higher in Grassland.

The spatial segregation of lichen growth forms between habitats may be indicative of lichen dispersal limitation (Werth et al. 2006) and/or the effect of abiotic factors on reproductive strategies. Lichens can reproduce asexually (i.e. soredia and isidia) and sexually; and may also produce

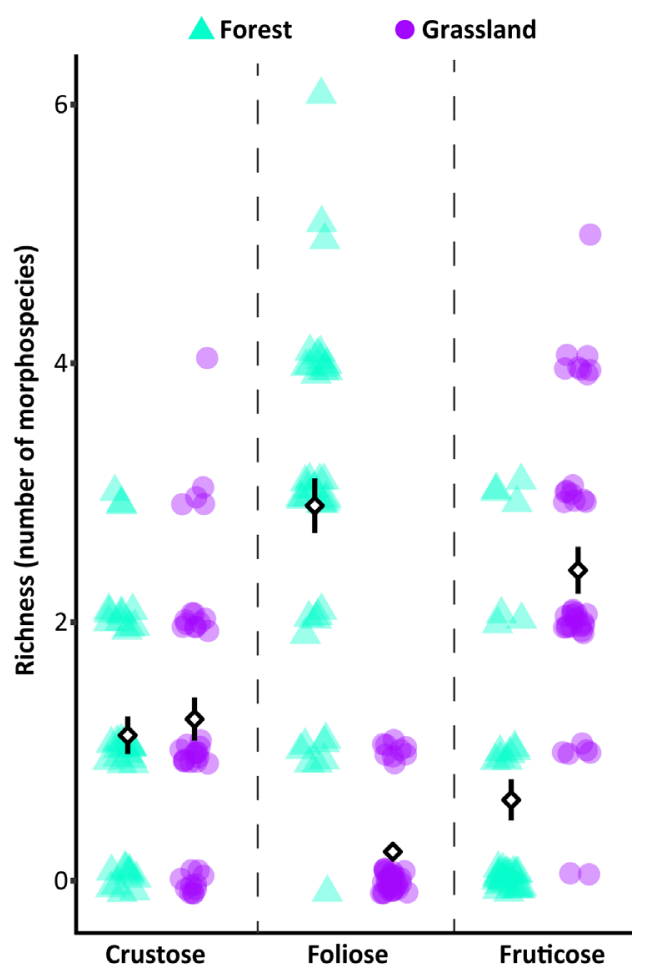

Figure 4. Scatterplot of cover (\%) and richness of lichen growth forms (crustose, foliose and fruticose) associated with Araucaria angustifolia tree trunks sampled in two habitats: "Forest" (blue triangles) and "Grassland" (purple circles) in Mixed Ombrophilous Forest. Black and white diamonds and black bars represent mean and standard errors, respectively. 


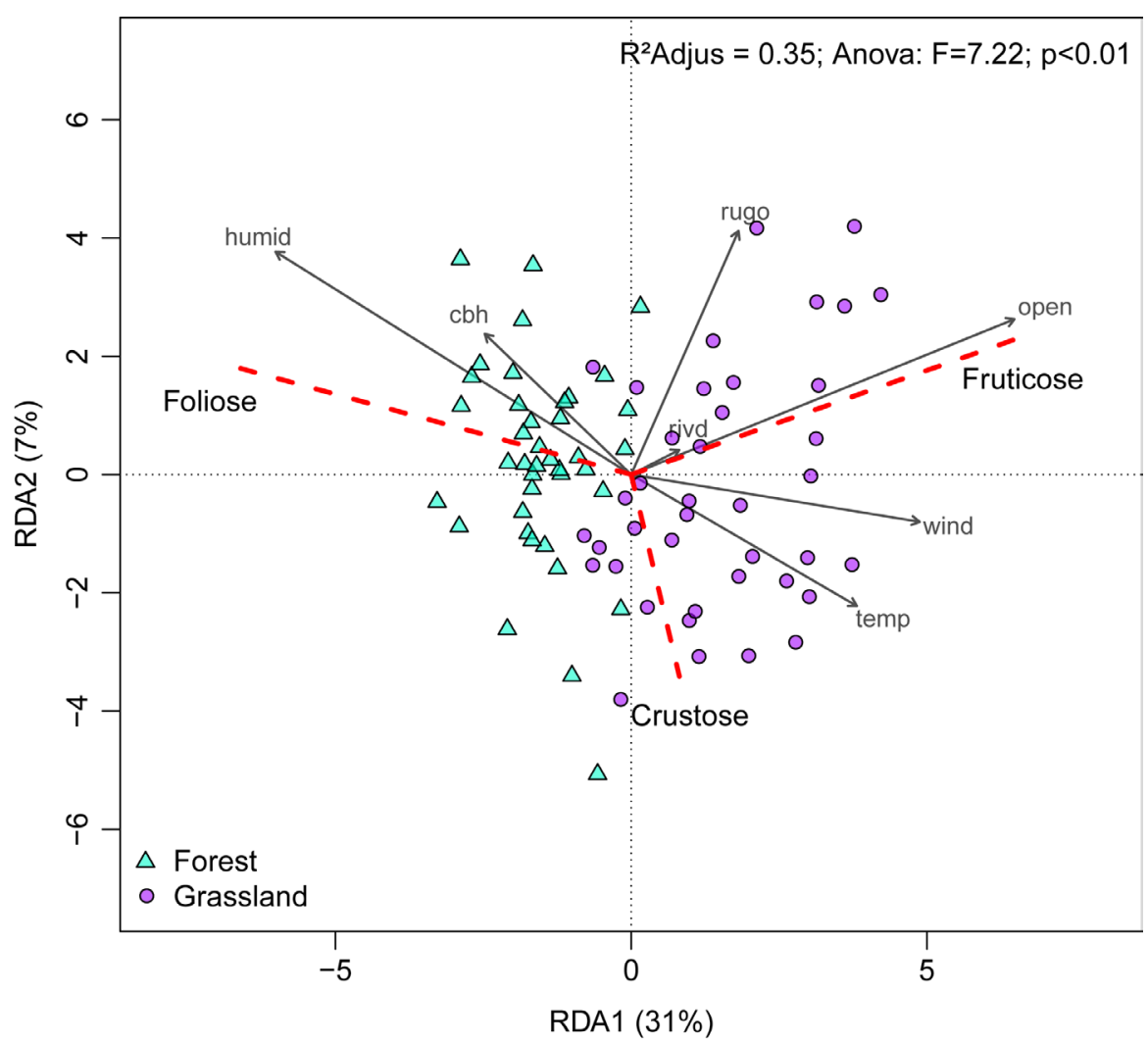

Figure 5. Redundancy analysis (RDA) between abiotic variables and lichen growth forms associated with Araucaria angustifolia tree trunks, sampled in two habitats ("Forest" and "Grassland") in Mixed Ombrophilous Forest. Arrows indicate abiotic variables: "open" - canopy openness; "cbh" - circumference at breast height; "rugo" - trunk rugosity; "temp" - air temperature $\left({ }^{\circ} \mathrm{C}\right)$; humid - air humidity (\%); wind - wind speed ( $\mathrm{m} / \mathrm{s}$ ). Red dashed lines represent the three growth forms of lichens (crustose, foliose and fruticose).

vegetative propagules (Bowler \& Rundel 1975; Seymour et al. 2005). These forms of reproduction result in different dispersal strategies. Sexual spores can be dispersed to long distances by wind and rain (Bowler \& Rundel 1975), whereas asexual reproduction limits dispersal distance but generates new thallus quicker than sexual spores after deposition on a substrate (Seymour et al. 2005). For instance, the fruticose growth form was observed in higher proportion in Grassland with a positive influence of canopy openness. Generally, this growth form is known to undergo symbiotic reproduction (i.e. many species of Usnea with fibrils), may have low dispersal capacity, and the growth of new individuals is dependent on the transport of fragments by vectors such as wind (Hinds \& Hinds 2007). The open canopy in Grassland facilitates dispersal of lichens by wind, which may explain the dominance of the fruticose growth form in this habitat. On the other hand, the foliose anatomy generates high adherence to the substrate, protecting the photobiont between the fungus cortical layers (Büdel \& Scheidegger 2008), thus requiring lower wind exposure and higher retention of humidity for the physiological maintenance of the algae (Hinds \& Hinds 2007; Koch et al. 2013). Hence, this growth form is favored by lower canopy openness that can act as a physical barrier against desiccation. Thus, we could infer that abiotic parameters influence dispersal ability and limit lichen establishment (Bowler \& Rundel 1975; Scheidegger \& Werth 2009).

Trunks of araucaria trees with high rugosity were less colonized by crustose lichens. The crustose growth form is characterized by high adherence to the substrate (Hinds \& Hinds 2007), therefore its occurrence is probably limited on trees with a high extent of bark peeling. This was corroborated by the presence of crustose lichens exclusively related to medium and low trunk rugosity in both habitats and less correlated with abiotic parameters. The crustose form is resistant to low light availability and can tolerate water oversaturation due to morphological adaptations (Lakatos et al. 2006). Thus, we may infer that the substrate (characteristics of araucaria trunks) was more relevant in the distribution of crustose lichens than other abiotic conditions.

These observations led to the hypothesis that the distribution of corticolous lichens in Forest and Grassland may be due to the existence of different optimum conditions required for their establishment and growth (Marcelli 1998; Gauslaa 2014). Especially considering abiotic conditions, water availability or saturation is a key parameter, as it influences $\mathrm{CO}_{2}$ exchange on the surface of the lichen thallus (Harris 1971; Lakatos et al. 2006) and acts as a 
dispersal mechanism for reproductive stages (Scheidegger $\&$ Werth 2009). For instance, in conditions of low humidity, higher canopy openness and higher substrate rugosity (observed in Grassland), there is less substrate available for establishment and less water for the physiological maintenance of the photobiont. These conditions may reduce richness in Grassland when compared to Forest. However, an increase in humidity would create a niche overlap with other species that require increased water availability to survive, such as mosses and ferns (Friedel et al. 2006). The niche overlap concept (Pianka 1974) assumes that an environment in which species share their resources may support a more diverse community than those where this partition of resources does not occur. Pianka's theory reinforces our finding that Forest has the highest species richness considering that the increase in humidity can favor lichen growth, but can also lead to competition for space, affecting their coexistence.

The higher richness of lichen morphospecies observed in Forest was possibly related to the interaction among the abiotic variables in this habitat. These variables were more constant (i.e. lower range of values) than in Grassland, which could favor a diversification of morphospecies. In contrast, the high variability of each abiotic factor in Grassland could act as a "filter effect". In this case, reduced richness may be related to the ability of species to establish and disperse in this habitat. The filter effect is corroborated by the composition of lichens in each area, with high segregation of the foliose growth form in Forest. Conversely, the interaction of abiotic parameters was more important for determining the composition of crustose and fruticose lichens.

Our study reinforces the importance of abiotic factors in the spatial distribution and species composition of lichen communities on Araucaria angustifolia trunks. As a consequence, we highlight the relevance of conservation of populations of the endangered species A. angustifolia (Brasil 2008), as well as of the protection of Mixed Ombrophilous Forest remnants in southern Brazil.

\section{Acknowledgements}

We thank Eduardo H. Giehl for the assistance with statistical analysis; and Bruna de Ramos for the support with the CPCe software. We also thank to the owners and managers of the Reunidas Campo Novo farm for the structural support. We thank the Programa de Pósgraduação em Ecologia-UFSC for essential financial and field support. LN, GB and MSD are supported by a scholarship from CAPES.

\section{References}

Bähring A, Fichtner A, Ibe K, et al. 2016. Ecosystem functions as indicators for heathland responses to nitrogen fertilisation. Ecological Indicators 72: 185-193.
Beck A, Friedl T, Rambold G. 1998. Selectivity of photobiont choice in a defined lichen community: inferences from cultural and molecular studies. New Phytologist 139: 709-720.

Benítez Á, Prieto M, González Y, Aragón G. 2012. Effects of tropical montane forest disturbance on epiphytic macrolichens. Science of the Total Environment 441: 169-175.

Borgo M, Silva SM. 2003. Epífitos vasculares em fragmentos de Floresta Ombrófila Mista, Curitiba, Paraná, Brasil. Revista Brasileira de Botânica 26: 391-401.

Bowler PA, Rundel PW. 1975. Reproductive strategies in lichens. Botanical Journal of the Linnean Society 70: 325-340.

Brasil. 2008. Instrução normativa n. 6 de 26 de setembro de 2008. Lista oficial das espécies da flora brasileira ameaçadas de extinção. Brasília, MMA.

Brodo IM. 1973. Substrate ecology. In: Ahmadjian V, Hale ME. (eds.). The lichens. New York, Academic Press. p. 401-441.

Büdel B, Scheidegger C. 2008. Thallus morphology and anatomy. In: Nash TH. (ed.) Lichen biology. 2nd edn. Cambridge, Cambridge University Press. p. 40-68

Büdel B, Colesie C, Green TGA, et al. 2014. Improved appreciation of the functioning and importance of biological soil crusts in Europe: The Soil Crust International Project (SCIN). Biodiversity and Conservation 23: 1639-1658.

Concostrina-Zubiri L, Huber-Sannwald E, Martínez I, Flores JL, Escudero A. 2013. Biological soil crusts greatly contribute to small-scale soil heterogeneity along a grazing gradient. Soil Biology and Biochemistry 64: 28-36.

Cornelissen JHC, Lang SI, Soudzilovskaia NA, During HJ. 2007. Comparative cryptogam ecology: A review of bryophyte and lichen traits that drive biogeochemistry. Annals of Botany 99: 987-1001.

Das P, Joshi S, Rout J, Upreti DK. 2012. Impact of anthropogenic factors on abundance variability among lichen species in southern Assam, north east India. Tropical Ecology 54: 67-72.

Dettki H, Esseen PA. 1998. Epiphytic macrolichens in managed and natural forest landscapes: a comparison at two spatial scales. Ecography 21: 613-624.

Fedrowitz K, Kaasalainen U, Rikkinen J. 2012. Geographic mosaic of symbiont selectivity in a genus of epiphytic cyanolichens. Ecology and Evolution 2: 2291-2303.

Fleig M, Grüninger W. 2008. Lichens of the Araucaria Forest of Rio Grande do Sul. Pro-Mata: field guide No. 3. Tübingen, University of Tübingen.

Fogaça IB, Cerveira A, Scheer GG, Maia H, Gomes TC, Dechoum MS. 2016. Pode Araucaria angustifolia ser considerada uma espécie facilitadora no processo de conversão de campos em florestas? In: Teixeira TR, Agrelo M, Segal B, Hanazaki N, Giehl ELH. (eds.). Ecologia de campo - do mar às montanhas. Florianópolis, PPGECO/UFSC. p. 151-163.

Friedel A, Oheimb GV, Dengler J, Hardtle W. 2006. Species diversity and species composition of epiphytic bryophytes and lichens - a comparison of managed and unmanaged beech forests in NE Germany. Feddes Repertorium 117: 172-185.

Gauslaa Y. 2014. Rain, dew, and humid air as drivers of morphology, function and spatial distribution in epiphytic lichens. The Lichenologist 46: 1-16.

Giordani P, Brunialti G, Benesperi R, Rizzi G, Frati F, Modenesi P. 2009. Rapid biodiversity assessment in lichen diversity surveys: implications for quality assurance. Journal of Environmental Monitoring 11: 730-735.

Hampp R, Cardoso N, Fleig M, Grüninger W. 2018. Vitality of lichens under different light climates in an Araucaria forest (Pró-mata RS, south Brazil) as determined by chlorophyll fluorescence. Acta Botanica Brasilica 32: 188-197.

Harris GP. 1971. The ecology of corticolous lichens II. the relationship between physiology and the environment. Journal of Ecology 59: 441-452.

Heinken T. 1999. Dispersal patterns of terricolous lichens by thallus fragments. The Lichenologist 31: 603-612.

Hinds JW, Hinds PL. 2007. The macrolichens of New England. New York, The New York Botanical Garden Press. 
Honda NK, Vilegas W. 1998. The chemistry of lichens. Química Nova 21: $110-125$.

Hueck K. 1953. Distribuição e habitat natural do Pinheiro do Paraná (Araucaria angustifolia) Boletim da Faculdade de Filosofia, Ciências e Letras, Universidade de São Paulo, Botânica 10: 5-24.

Käffer MI, Ganade G, Marcelli MP. 2009. Lichen diversity and composition in Araucaria forests and tree monocultures in southern Brazil. Biodiversity and Conservation 18: 3543-3561.

Käffer MI, Marcelli MP, Ganade G. 2010. Distribution and composition of the lichenized mycota in a landscape mosaic of southern Brazil. Acta Botanica Brasilica 24: 790-802.

Käffer MI, Martins SMA. 2014. Evaluation of the environmental quality of a protected riparian forest in Southern Brazil. Bosque 35: 325-336.

Käffer MI, Koch NM, Aptroot A, Martins SMA. 2015. New records of corticolous lichens for South America and Brazil. Plant Ecology and Evolution 148: 111-118.

Koch NM, Maluf RW, Martins SMA. 2012. Foliose lichen community on Piptocarpha angustifolia Dusén ex Malme (Asteraceae) in an area of native Araucaria forest in Rio Grande do Sul State, Brazil. Iheringia 67: 47-57.

Koch NM, Martins SMDA, Lucheta F, Müller SC. 2013. Functional diversity and traits assembly patterns of lichens as indicators of successional stages in a tropical rainforest. Ecological Indicators 34: 22-30.

Kohler KE, Gill SM. 2006. Coral Point Count with Excel extensions (CPCe): A visual basic program for the determination of coral and substrate coverage using random point count methodology. Computers and Geosciences 32: 1259-129.

Lakatos M, Rascher U, Büdel B. 2006. Functional characteristics of corticolous lichens in the understory of a tropical lowland rain forest. New Phytologist 172: 679-695.

Lemos A, Kaffer MI, Martins SA. 2007. Composição e diversidade de líquens corticícolas em três diferentes ambientes: Florestal, Urbano e Industrial. Revista Brasileira de Biociências 5: 228-230.

Li S, Liu WY, Li DW. 2013. Epiphytic lichens in subtropical forest ecosystems in southwest China: Species diversity and implications for conservation. Biological Conservation 159: 88-95.

Marcelli MP. 1998. History and current knowledge of brazilian lichenology. In: Marcelli MP, Seaward MRD. (eds.). Lichenolgy in Latin America: Hystory, current knowledge and applications. São Paulo, CETESB. p. 25-45.

Marcelli MP. 2006. Fungos liquenizados. In: Xavier Filho L, Legaz ME, Cordoba CV, Pereira EC. (eds.) Biologia de líquens. Rio de Janeiro, Âmbito Cultural Edições, Ltda. p. 25-74.

Martins SMA, Käffer MI, Alves CR, Pereira VC. 2011. Fungos liquenizados da Mata Atlântica, no sul do Brasil. Acta Botanica Brasilica 25: 286-292.

McMullin RT, Duinker PN, Richardson DHS, Cameron RP, Hamilton DC, Newmaster SG. 2010. Relationships between the structural complexity and lichen community in coniferous forests of southwestern Nova Scotia. Forest Ecology and Management 260: 744-749.

Medeiros JD, Savi M, Brito BFA. 2005. Seleção de áreas para criação de Unidades de Conservação na Floresta Ombrófila Mista. Biotemas 18: 33-50.
Moning C, Werth S, Dziock F, et al. 2009. Lichen diversity in temperate montane forests is influenced by forest structure more than climate. Forest Ecology and Management 258: 745-751.

Munir TM, Perkins M, Kaing E, Strack M. 2015. Carbon dioxide flux and net primary production of a boreal treed bog: Responses to warming and water-table-lowering simulations of climate change. Biogeosciences 12: 1091-1111.

Nascimbene J, Marini L, Motta R, Nimis PL. 2009. Influence of tree age, tree size and crown structure on lichen communities in mature Alpine spruce forests. Biodiversity and Conservation 18: 1509-1522.

Nash TH. 2008. Lichen biology. 2nd. edn. Cambridge, Cambridge University Press.

Nimis PL, Scheidegger C, Wolseley PA. 2002. Monitoring with lichens monitoring lichens. NATO Science Series. IV. Earth and Environmental Sciences, 7. Dordrecht, Kluwer Academic Publishers.

Oksanen JF, Blanchet G, Kindt R, et al. 2013. Vegan: Community Ecology Package. R package version 2.0-10. http://CRAN.R-project.org/ package=vegan

Palmqvist K. 2000. Carbon economy in lichens. New Phytologist 148: 11-36.

Pandolfo C, Braga HJ, Silva Júnior VP, et al. 2002. Atlas climatológico do Estado de Santa Catarina. Florianópolis, Epagri.

Perlmutter GB, Blank GB, Wentworth TR, Lowman MD, Neufeld HS, Rivas Plata E. 2017. Effects of highway pollution on forest lichen community structure in western Wake County, North Carolina, U.S.A. The Bryologist 120: 1-10.

Pianka ER. 1974. Niche overlap and diffuse competition. Proceedings of the National Academy of Sciences of the United States of America 71: 2141-2145.

R CoreTeam. 2017. R: A language and environment for statistical computing. Vienna, The R Foundation for Statistical Computing.

Rondon Neto RM, Watzlawick LF, Caldeira MVW, Schoeninger ER. 2002. Análise florística e estrutural de um fragmento de floresta ombrófila mista montana, situado em Criúva, RS Brasil. Ciência Florestal 12: 29-37.

Scheidegger C, Werth S. 2009. Conservation strategies for lichens: insights from population biology. Fungal Biology Reviews 23: 55-66.

Seymour FA, Crittenden PD, Dyer PS. 2005. Sex in the extremes: lichenforming fungi. Mycologist 19: 51-58.

Spribille T, Tuovinen V, Resl P, et al. 2016. Basidiomycete yeasts in the cortex of ascomycete macrolichens. Science 353: 488-492.

Werth S, Wagner HH, Gugerli F, Holderegger R, Csencsics D, Kalwij JM, Scheidegger C. 2006. Quantifying dispersal and establishment limitation in a population of an epiphytic lichen. Ecology 87: 20372046.

Wickham H. 2009. ggplot2: elegant graphics for data analysis. New York, Springer New York.

Will-Wolf S, Geiser LH, Neitlich P, Reis AH. 2006. Forest lichen communities and environment - How consistent are relationships across scales? Journal of Vegetation Science 17: 171-184. 